\title{
Międzykulturowe otwarcie szkoły jako odpowiedź na potrzeby ucznia z doświadczeniem migracyjnym. Na przykładzie migracji powrotnych
}

\begin{abstract}
STRESZCZENIE
Dziecko z doświadczeniem migracyjnym coraz częściej staje się uczniem polskiej szkoły, która nie jest do końca na to przygotowana. Szczególnym typem doświadczenia migracyjnego są migracje powrotne, kiedy to rodzina po okresie spędzonym za granicą wraca do kraju wraz z dziećmi, urodzonymi jeszcze w kraju pochodzenia rodziców bądź już na emigracji. Obecnie mamy do czynienia z nasilającymi się procesami remigracji, co sprawia, że również szkoły powinny być przygotowane na przyjęcie uczniów „powracających”, najczęściej dwujęzycznych, a jednocześnie z pewnymi ograniczeniami w zakresie znajomości języka polskiego, którzy muszą borykać się z różnicami programowymi oraz kulturowymi, m.in. dotyczącymi kultury szkoły. Wydaje się, że idea międzykulturowego otwarcia instytucji, którą można za niemiecką pedagogiką międzykulturową odnieść również do szkoły, daje narzędzia do przygotowania instytucji na funkcjonowanie w sytuacji wysokiej różnorodności społecznej i kulturowej.

Celem artykułu jest przedstawienie idei międzykulturowego otwarcia szkoły jako odpowiedzi na potrzeby ucznia z doświadczeniem migracyjnym na przykładzie dziecka z rodziny remigrantów. Na początku przedstawiona zostanie teoria międzykulturowego otwarcia instytucji, w tym szkoły, następnie zaś omówiona będzie specyfika ucznia „powracającego” w oparciu o wyniki badań jakościowych prowadzonych w warszawskich szkołach podstawowych, by w podsumowaniu możliwe było przedstawienie idei
\end{abstract}

${ }^{1}$ Katarzyna Stankiewicz, Instytut Pedagogiki, Uniwersytet Gdański, Polska, e-mail: k.stankiewicz@ ug.edu.pl. 
międzykulturowego otwarcia szkoły jako odpowiedzi na potrzeby ucznia z rodziny reemigrantów, jak również uczniów z innym typem doświadczenia migracyjnego. Międzykulturowe otwarcie szkoły zostanie również odniesione do procesu integracji społecznej migrantów, co pozwala widzieć placówki szkolne w szerszym kontekście działania sieci instytucji najbliższego otoczenia społecznego na rzecz efektywnej adaptacji społecznej oraz (re)integracji całej powracającej rodziny.

\section{Słowa kluczowe:}

międzykulturowe otwarcie, uczeń z doświadczeniem migracyjnym, uczeń „powracający”, migracja powrotna, remigracja, edukacja szkolna, integracja

\section{ABSTRACT}

Children with migration experience are increasingly becoming students in the Polish school system that is not prepared for it. The special type of migration experience is what is called "the return migration", when a family returns to a country after some time abroad, together with their children, that were born in the country of origin of their parents or already in exile. Currently, we are experiencing an intensification of the remigration processes, which means that schools should also be prepared to receive "returning" students, who are mostly bilingual, and at the same time with some difficulties with the Polish language, who have to deal with program and cultural differences, among others school poicies and culture. It seems that the idea of an intercultural opening of institution also refers to schools, what was told by German intercultural pedagogs, provides tools for preparing institutions for functioning in a situation of high social and cultural diversity.

The aim of the article is to present the idea of intercultural opening of school as a response to the needs of students with migration experience concentrating on an example of a child from a remigrant family. At the beginning, the theory of intercultural institution opening will be presented, including the school, then the specificity of the "returning" student will be discussed, on the basis of the results of qualitative research conducted in Warsaw primary schools, in order to present the idea of intercultural opening of school as a response to the needs of the students from a family of remigrants, as well as students with a different type of migration experience. The process of the intercultural school opening will also be related to the process of social integration of migrants, which allows to see schools in the broader context of the network of institutions of the closest social environment for effective social adaptation and (re) integration of the whole returning family.

\section{Keywords:}

intercultural opening, student with migration experience, „,returning“ student, return migration, remigration, school education, integration 
Dziecko z doświadczeniem migracyjnym coraz częściej staje się uczniem polskiej szkoły, która nie jest do końca na to przygotowana (por. Błeszyńska, 2010; Januszewska, 2015). Szczególnym typem doświadczenia migracyjnego są migracje powrotne, kiedy to rodzina po okresie spędzonym za granicą wraca do kraju wraz z dziećmi, urodzonymi jeszcze w kraju pochodzenia rodziców bądź już na emigracji. Obecnie mamy do czynienia z nasilającymi się procesami remigracji (patrz np. Latek, 2017; Sosnowska, 2017), co sprawia, że również szkoły powinny być przygotowane na przyjęcie uczniów „powracających”2, najczęściej dwujęzycznych, a jednocześnie z pewnymi ograniczeniami w zakresie znajomości języka polskiego, którzy muszą borykać się z różnicami programowymi czy kulturowymi (por. Grzymała-Moszczyńska i in., 2015). Wydaje się, że idea międzykulturowego otwarcia instytucji, którą można za niemiecką pedagogiką międzykulturową odnieść również do szkoły, daje narzędzia do przygotowania instytucji do funkcjonowania w sytuacji wysokiej różnorodności społecznej i kulturowej.

Celem artykułu jest przedstawienie idei międzykulturowego otwarcia szkoły jako odpowiedzi na potrzeby ucznia z doświadczeniem migracyjnym na przykładzie dziecka z rodziny migrantów powrotnych. Wyjdę od przedstawienia teorii międzykulturowego otwarcia instytucji, w tym szkoły, następnie zaś omówię specyfikę funkcjonowania szkolnego ucznia powracającego, wykorzystując wyniki badań jakościowych prowadzonych przeze mnie w 2018 roku w warszawskich szkołach podstawowych, by w podsumowaniu przedstawić wreszcie ideę międzykulturowego otwarcia szkoły jako odpowiedź na potrzeby ucznia z rodziny remigrantów, jak również uczniów z innym typem doświadczenia migracyjnego. Międzykulturowe otwarcie szkoły odniosę również do procesu integracji społecznej migrantów, za przykład biorąc politykę miejską Gdańska w tym zakresie, co pozwoli spojrzeć na placówki szkolne w szerszym kontekście działania sieci instytucji najbliższego otoczenia społecznej na rzecz efektywnej adaptacji społecznej oraz (re)integracji całej powracającej rodziny.

${ }^{2}$ Użyłam tutaj określenia „,powracający” w cudzysłowie, chcąc się do niego nieco zdystansować i podkreślić, że nie każdy uczeń z rodziny migrantów powrotnych, sam jest remigrantem; powrót dotyczy w pierwszej kolejności rodziców, dziecko mogło urodzić się już za granicami kraju. W dalszej części artykuł pomijam cudzysłów. 


\section{IDEA MIĘDZYKULTUROWEGO OTWARCIA SZKOŁY}

Międzykulturowe otwarcie instytucji to idea wywodząca się z gruntu amerykańskiego, wypracowana w latach 80 . XX wieku w ramach teorii zarządzania organizacją, popularna w Niemczech począwszy od późnych latach 80. i wykorzystywana na potrzeby pracy socjalnej oraz pedagogiki międzykulturowej, doskonale wpisująca się w założenia tej ostatniej (Leiprecht, 2008; Schanz, 2006). Wcześniej niemieccy teoretycy i praktycy integracji społeczno-kulturowej imigrantów mówili o międzykulturowym ukierunkowaniu instytucji, wskazując na konieczność jej zmiany i dostosowania się do rosnącej różnorodności kulturowej społeczeństwa. Idea międzykulturowego otwarcia umożliwiła przygotowanie określonych narzędzi, pozwalających na realizację międzykulturowej orientacji instytucji i zarządzanie różnorodnością w jej ramach. Otwarta międzykulturowo instytucja, w tym szkoła, staje się elementem szerszego systemu społecznego i ma działać według nowych zasad, które służą przekraczaniu dotychczasowych ograniczeń i tworzeniu sieci powiązań ze środowiskiem lokalnym. Tym samym staje się instrumentem realizacji polityki integracyjnej i spójnościowej, co na poziomie szkoły oznacza nie tylko działania na rzecz wyrównywania szans uczniów z doświadczeniem migracyjnym, ale również przygotowanie pracowników i całej szkolnej społeczności do funkcjonowania w warunkach społecznej i kulturowej różnorodności i czerpania z niej profitów (Vanderheiden, Mayer, 2014, s. 21-24; por. Handschuck, Schröer, 2012).

Międzykulturowe otwarcie można traktować zatem jako ideę niezwykle istotną dla rozwoju instytucji, odpowiadającą na potrzeby zmieniającego się świata. Celem międzykulturowego otwarcia instytucji jest zapewnienie równego dostępu do usług oraz równego traktowania wszystkim zainteresowanym osobom, niezależnie od ich pochodzenia, ale też płci czy wieku. To nowe otwarcie ma umożliwić współtworzenie instytucji przez samych odbiorców jej oferty. Tym samym wpisuje się w nurt działań na rzecz środowiska włączającego. Obejmując swoim zakresem różne instytucje, zapewnia proces inkluzji we wszystkich istotnych obszarach życia społecznego (Schmitt, 2016).

Międzykulturowe otwarcie możemy traktować - za niemieckimi pedagogami międzykulturowymi - jako zmianę paradygmatu, która pozwala na przejście od strategii asymilacyjne do integracyjnej w stosunku do imigrantów. Zmiana dotyczy paradygmatycznego przejścia (Schröer, Szukitsch. 2016, s. 5):

1) od orientacji na mniejszości do zainteresowania społeczeństwem przyjmującym, grupą większościową;

2) od koncentrowania się na deficytach przedstawicieli mniejszości do poszukiwania ich potencjału; 
3) od rozwoju jednostki do rozwoju organizacji;

4) od zmiany organizacji do dążenia do zmiany społecznej.

Jedną z instytucji, która może podlegać międzykulturowemu otwarciu, jest właśnie wspomniana już szkoła, o czym pisze Claudia Schanz (2006) ${ }^{3}$. U podstaw wprowadzenia do szkoły idei międzykulturowego otwarcia leżą dwa założenia. Zdaniem Schanz szkoła odbija zróżnicowanie społeczno-kulturowe społeczeństwa, musi sobie z tym zróżnicowaniem radzić, a najlepiej czerpać z niego korzyści, rozwijać potencjał każdego ucznia, niezależnie od jego pochodzenia. Jednocześnie szkoła ma za zadanie przygotowywać do życia w dobie integracji europejskiej, rosnącej mobilności i globalizacji, w środowisku zróżnicowanym kulturowo (Schanz, 2006, s. 110-111).

Otwarcie międzykulturowe możemy traktować jako formę przeciwdziałania wykluczeniu uczniów z doświadczeniem migracyjnym. Za C. Schanz (2006, s. 18) wyróżniamy „otwarcie wewnętrzne” szkoły, które polega na przekroczeniu ograniczeń w ramach samej instytucji. Dąży się do większej indywidualizacji procesu nauczania, zróżnicowania metod nauczania i dostosowania ich do potrzeb uczących się, przełamania granic między latami nauki i przedmiotami, większego zaangażowania samych uczniów w proces edukacji, wspierania wielojęzyczności oraz rozbudzanie zainteresowania kadry procesami komunikowania się w szkole. Służyć ma temu przyjęcie międzykulturowej misji szkoły, wpisującej się w założenia pedagogiki międzykulturowej, która jest nie tyle ukierunkowana na braki „innego”, co wskazuje drogę kształcenia całej społeczności szkolnej tak, aby możliwe było czerpanie profitów ze społecznej i kulturowej różnorodności. Możemy mówić również o otwarciu szkoły „na zewnątrz”, które ma polegać na pogłębianiu związków instytucji z partnerami pozaszkolnymi, większym zaangażowaniu rodziców, demokratyzacji szkoły oraz pomocy zewnętrznego mentora od spraw międzykulturowych, który może z dystansem spojrzeć na relacje w szkole i zaprojektować proces zmian w kierunku zwiększenia inkluzyjności środowiska szkolnego (Schanz, 2006, s. 18-19; por. Auernheimer, 2017, s. 204-211).

Zdaniem Georga Auernheimera (2017, s. 205) szkoła powinna „uwzględniać kontekst społeczny i związaną z nim wielokulturowość, zwłaszcza wielojęzyczność, oraz inne następstwa migracji” (w tym dyskryminację). Autor jako elementy międzykulturowego otwarcia wymienia udział rodziców w pracy szkoły, pracę zespołową nauczycieli, wielojęzyczność personelu, doskonalenie zawodowe kadry, ukierunkowanie na kulturową różnorodność, partnerską atmosferę i demokratyczne

\footnotetext{
3 Por. koncepcję szkoły jako organizacji uczącej się (zob. np. Fullan, 1995).
} 
relacje w szkole, integrację poprzez zajęcia dodatkowe oraz otwartość szkoły na zewnątrz (Auernheimer, 2017, s. 204-211).

\section{SYTUACJA I POTRZEBY UCZNIA „POWRACAJĄCEGO”}

Dla zrozumienia specyfiki doświadczenia migracyjnego ucznia powracającego niezbędne jest poznanie przyczyn powrotu rodziny z emigracji. Istotny wydaje się również sam stosunek rodziców do powrotu i pobytu w Polsce. Halina Grzymała-Moszczyńska z zespołem pisze o pętli migracyjnej, w którą siłą rzeczy uwikłane są też dzieci, a która determinuje kolejne migracje całej rodziny czy jej członków. Jak czytamy w raporcie, wyjazd rodziców za granicę często powodowany jest czynnikami materialnymi. Pobyt na emigracji co prawda zapewnia rodzinie dobrą sytuację finansową, jednak wyzwala tęsknotę za ojczyzną i chęć powrotu, co jest z kolei przyczyną remigracji... Jednak powrót wiąże się z trudnościami adaptacyjnymi, które przyczyniają się do idealizacji pobytu na emigracji. Problemy, na które napotyka remigrant, skutkują kolejną decyzją o wyjeździe z kraju (Grzymała-Moszczyńska i in., 2015, s. 13; por. Iglicka, 2010).

Dziecko również boryka się z trudnościami w adaptacji do nowych warunków, w czym często rodzice nie stanowią wystarczającego wsparcia, ponieważ sami są obarczeni wieloma problemami, związanymi z przeprowadzką i próbą odnalezienia się w nowej sytuacji. Do decyzji o ponownej migracji przyczyniają się m.in. trudności dziecka w polskiej szkole, które wydają się dla rodziców potwierdzeniem niepowodzenia w adaptacji rodziny do polskich warunków (por. Grzymała-Moszczyńska i in., 2015, s. 28-30).

Uczeń powracający posiada określone doświadczenie migracyjne, które ma znaczenie dla jego postaw, zachowań, jak również posiadanej szkolnej wiedzy i umiejętności czy znajomości języków. Jego potrzeby i potencjał bywają niedostrzegane przez nauczycieli. Może on być bardzo różnie przez nich postrzegany i traktowany. Na pytanie o to, kim jest uczeń z rodziny remigrantów, odpowiedzi badanych nauczycieli bywają bardzo różne: normalny uczeń, dodatkowy nakład pracy, problem, zagadka, ale też wyzwanie ${ }^{4}$.

${ }^{4}$ Odpowiedzi nauczycieli na to pytanie zostały zebrane w toku badań (ankiety, wywiady), które prowadziłam w Warszawie od lutego do końca czerwca 2018 roku. Projekt badawczy dotyczy potrzeb i wsparcia ucznia powracającego. Formą badania pilotażowego była krótka ankieta, skierowana do nauczycieli pracujących z dziećmi z rodzin reemigrantów (12 osób). Do tej pory przeprowadziłam poza tym wywiady z 9 nauczycielkami warszawskich szkół podstawowych, którzy pracują z uczniami powracającymi, z czego 4 uczy na poziomie 1-3, z jedną pedagog oraz jedną psycholog pracującymi 
Najczęściej takie dziecko traktowane jest przez polskiego nauczyciela właśnie jako „zwyczajny uczeń”, który dołącza do zespołu klasowego, uczeń niewymagający dodatkowej uwagi ze względu na historię migracyjną. Jak mówi jedna z nauczycielek „dla szkoły uczeń powracający jest po prostu uczniem, ja nie widzę różnicy... Czasami większym wyzwaniem są ci uczniowie... ja nie wiem, jak ich nazwać... »tutejsi«... niż ci powracający z zagranicy” [WN7].

To bardzo popularne podejście nauczyciela do dziecka remigrantów, które wraca z dobrą znajomością mówionego języka polskiego, bezbłędną wymową i polskim akcentem. O ile różnice programowe stają się widoczne w zasadzie od początku nauki w nowej szkole, to różnice kulturowe mogą być niedostrzegane czy też bagatelizowane przez nauczycieli, którzy zakładają, że to „polskie dziecko”, wychowane przecież w polskiej rodzinie, zatem powinno bez problemu odnaleźć się w nowej szkole. Tymczasem już sama organizacja życia szkolnego w Polsce może się znacznie różnić od tego, z czym dziecko miało kontakt do tej pory.

Nauczyciele z uczniem powracającym kojarzą także „dodatkowy nakład pracy”, którą muszą poświęcić na przygotowanie materiałów dydaktycznych, dostosowanych do poziomu wiedzy i umiejętności dziecka. Jedna z nauczycielek uważa, że „taki uczeń powracający kojarzy się z dodatkowym nakładem pracy, bo to jest kolejny uczeń, który wymaga indywidualnego podejścia... Mamy w klasie uczniów... mamy grupę uczniów, którzy nie wymagają takiego indywidualnego podejścia, którzy sobie świetnie radzą sami, są zorganizowani, odpowiedzialni, samoobsługowi... Ale jest zawsze kilku takich, którzy wymagają indywidualnego podejścia i którzy zabierają, w cudzysłowie »zabierają«, dużo czasu...” [WN2].

W opiniach nauczycieli pojawiło się też określenie „problem”. Uczeń powracający staje się uczniem „trudnym”, sprawiającym problemy właśnie dlatego, że wymaga bardziej indywidualnego podejścia, czasami bywa nieprzewidywalny w swoim reakcjach i działaniach, co wynika przede wszystkim z różnic kulturowych.

Część nauczycieli podejdzie do ucznia z rodziny remigrantów jak do swego rodzaju „zagadki”, którą warto rozwikłać, jak do „niewiadomej”. Takiego pojęcia

w szkole, jedną pedagog zatrudnioną w poradni psychologiczno-pedagogicznej w Warszawie, jedną doradczynią metodyczną ds. pracy z uczniem z doświadczeniem migracyjnym, z dwiema matkami remigrantkami, 3 trenerkami wspierającymi nauczycieli w zakresie pracy z uczniem z doświadczeniem migracyjnym, jedną niezależną ekspertką w tym temacie oraz z trzema przedstawicielkami warszawskich instytucji publicznych odpowiadających za doskonalenie nauczycieli. W tym artykule wykorzystuję głównie wypowiedzi nauczycielek. Przy cytatach podane są kody poszczególnych wywiadów (N - oznacza nauczycielki, R - rodziców, E - eksperta). Planowana jest kontynuacja w kolejnym roku szkolnym. 
używają ci nauczyciele, którzy starają się być ostrożni w swoich ocenach, podchodzą indywidualnie do każdego dziecka i są świadomi, że za historią migracyjną dziecka wiele się kryje; może ona znacząco wpływać na jego zachowania w szkole, czasami trudne do interpretacji czy przewidzenia.

Wreszcie w opiniach nauczycieli pracujących z uczniem powracającym pojawia się znaczące określenie „wyzwanie”, które pokazuje otwartość owych pedagogów, chęć uczenia się, poznawania nowych kultur itp. Dla przykładu jedna z moich rozmówczyń uważa, że „uczeń powracający jest dla nauczyciela taką możliwością poznawania i porównywania systemów edukacyjnych z innych krajów [WN5]”. Nauczyciele traktujący kształcenie dziecka powracającego z emigracji jako wyzwanie mają najczęściej świadomość tego, że ten uczeń wymaga nieco innego traktowania i wyjątkowej uwagi, ponieważ może się różnić od swoich rówieśników. Będzie to oznaczało dla nauczycieli z nim pracujących konieczność dokształcenia się, poznania samego dziecka, jego doświadczenia migracyjnego i sytuacji rodzinnej, a często również przygotowania materiałów dydaktycznych, uwzględniających różnice programowe i inne.

Warto zatrzymać się dłużej na pierwszym określeniu, które przywołują nauczycieli pracujący z uczniami z rodzin remigrantów. Niedostrzeganie specyficznych potrzeb tej grupy uczniów dobitnie pokazuje skierowana do mnie pod koniec rozmowy wypowiedź nauczycielki uczestniczącej w badaniu: „Widzi Pani... Ja nie do końca rozumiem Pani problemu z tymi dziećmi powracającymi, że one mogą mieć jakieś inne trudności niż reszta dzieci... No co? Że kultura inna?” [WN7].

Traktowanie uczniów powracających jako „zwyczajnych uczniów” niejako deprecjonuje ich historię migracyjną, przekreśla znaczenie różnic kulturowych, zasadność przeżywania trudności adaptacyjnych itp. ${ }^{5}$ Tymczasem należałoby uświadomić pedagogom, że dzieci remigrantów często nie są nawet urodzone w Polsce, jest to dla nich jedynie kraj ich rodziców czy też dziadków, kraj pochodzenia, w którym co najwyżej spędzali do tej pory wakacje i święta. Nawet jeżeli są to dzieci urodzone w Polsce, to często wczesne dzieciństwo spędzone w kraju nie zapisało się w ich pamięci. Normy kulturowe wyniesione z domu nie pokrywają całego spektrum sytuacji, z którymi spotykają się oni w szkole. Dzieci „powracające” faktycznie nie powracają „do siebie” - do swojego kraju, ale do kraju rodziców, a w Polsce stają się „ukrytymi migrantami” (Grzymała-Moszczyńska i in., 2015, s. 34).

${ }^{5}$ Nauczycielki, z którymi rozmawiałam, początkowo często stwierdzające, że nie ma sensu wyróżniać grupy uczniów powracających, bo nie mają oni specyficznych potrzeb, już po chwili rozmowy i refleksji nad specyfiką szkolnego funkcjonowania uczniów powracających same dostrzegają, że jednak się myliły. 


\section{SYTUACJA UCZNIA POWRACAJĄCEGO W PERSPEKTYWIE UCZNIÓW, RODZICÓW I NAUCZYCIELI}

Sytuację uczniów powracających w polskich szkołach opisano już w raporcie (Nie) łatwe powroty do domu? (Grzymała-Moszczyńska i in., 2015). Wiele ważnych informacji znalazło się też w materiałach poprojektowych (Z)Powrotem w Polsce (Białek, 2015 i 2016). Główne wnioski i spostrzeżenia zasadniczo pokrywają się ze wstępnymi wynikami moich badań. Dalej, korzystając z zebranych wypowiedzi rodziców, nauczycieli i innych osób pracujących z remigrantami, jak również z cytatów zamieszczonych w materiałach uwzględniających opinie rodziców i nauczycieli, opisuję specyfikę sytuacji ucznia powracającego.

Jego również dotyczy doświadczenie, sformułowane dobitnie przez jedną z mam, która wróciła z dziećmi z zagranicy, aktywnie działającą na rzecz remigrantów w ramach trzeciego sektora: „Tutaj wraca się jakby w próżnię. Wszyscy mają swoje życie, swoje sprawy...” [WR1]. Inny rodzic mówi o swoich odczuciach związanych z wysyłaniem dziecka do polskiej szkoły, w której nowy uczeń nie jest wcale przyjmowany z otwartością, podobnie jak zapisujący go rodzice, zmuszeni do poradzenia sobie z szeregiem wstępnych formalności i zmieszczenia się w ramy sztywnego systemu edukacji... „Czujesz, że sprawiasz kłopot, bo wracasz w nieodpowiednim terminie, bo nie masz ocen, punktów, testów; potencjał dziecka, jego zainteresowania, zdolności, znajomość języków, otwarcie na świat, znajomość języka - to nie ma znaczenia. Przykre” (Białek, 2015, s. 16).

Do tego dochodzą problemy emocjonalne. Uczeń jest „nowy”, może mieć trudności językowe, nie wszystko rozumie, standardy kulturowe, znane wszystkim uczniom, dla niego są obce. Czuje się sam, bywa izolowany, na różne sposoby zabiega o uznanie klasy, przechodzi proces adaptacji, który wymaga od niego wiele starań. „Tak się jakoś utarło, że on nie wchodził w te relacje w klasie. Izolował się. Na początku nawet iskrzyło między nimi. To znaczy, zdarzało się, że się nie dogadywali, nie rozumieli... Natomiast w trzeciej klasie, jak ja go objęłam, on zrobił bardzo duży skok, jeśli chodzi o sposób wypowiadania się [...]. Uczniowie zobaczyli go od trochę innej strony - że on wcale nie jest taki, że on się nie izoluje, ale że wiele nie rozumiał, on zwyczajnie przez ten czas uczył się tego języka...” [WN5].

Trudności emocjonalne pogłębia fakt, że dziecko przeżywa rozłąkę ze swoim poprzednim środowiskiem, tęskni za dawną szkołą, miejscem zamieszkania, kolegami... „Pewnie trudne dla niego było to, że się oderwał od swojego środowiska tam. Co prawda wrócił z rodzicami i braćmi, ale ja zaobserwowałam taką tęsknotę, bo to tam w Irlandii znał już kolegów” [WN7]. 
Nowy jest nie tylko kraj, miejsce zamieszkania, dzielnica, ale też szkoła - ze swoją odrębną od tej znanej dziecku do tej pory kulturą organizacyjną. Najczęściej panują tu odmienne, głównie te niepisane reguły zachowania, wiele rzeczy jest trudnych do zaakceptowania, wzmaga tęsknotę czy nawet frustrację. „Ogromnym problemem było przedstawienie się ze szkoły irlandzkiej na polską, ze sposobu prowadzenia zajęć. On był przyzwyczajony tylko do zabawy i do uczenia się metodą projektu, która polegała na tym że dzieci były cały czas w ruchu. Dla niego ta nasza ławeczka była trochę za ciasna. To jest przepaść między tym, co jest tu w szkole, a co jest w Irlandii. Tam już się przyzwyczaił, znał reguły postępowania, a w Polsce było inaczej i to było dla niego problemu. Trudno mu było się z tym pogodzić” [WN7].

Różnice dotyczą też metodyki nauczania, poczynając od nauki pisania. „Inny też jest sposób uczenia pisania w Irlandii - dzieci piszą, nie łącząc literek. Dla niego to łączenie było takie jakieś... »Ale o co tej Pani chodzi?«. [...]. A poza tym oni tam piszą bez linijek czy kratek, na gładkim papierze... I tutaj mieszczenie się na siłę w tych linijkach to dla niego jakaś głupota. Nie mógł tego zrozumieć” [WN7]. Pewne uwagi nauczyciela mogą być odbierane jako bezzasadne, wręcz absurdalne. Często nie jest łatwo się im podporządkować, dostosować do nowych wymagań.

Mimo komunikacyjnej znajomości języka polskiego, która z reguły jest udziałem dzieci migrantów powrotnych, brakuje uczniom słownictwa specjalistycznego, co przekłada się między innymi na problem z rozumieniem poleceń. Trudności może sprawiać również rozumienie języka pisanego. Jeden z uczniów przyznaje: „Czasem coś czytam w podręczniku i nic nie rozumiem. Nie wiem, jak zrobić ćwiczenia i w ogóle o co chodzi... Pani [...] obniża mi ocenę i to mnie bardzo denerwuje, bo znałam właściwą odpowiedź” (Białek, 2015, s. 23). Wypowiedź ta pokazuje również problemy z ocenianiem uczniów powracających - nieadekwatność oceny osiągnięć ucznia może wynikać z jego braku znajomości słownictwa specjalistycznego i trudności w zrozumieniu poleceń.

Również nauczycielki, z którymi rozmawiałam, dostrzegały problemy uczniów ze zrozumieniem poleceń, które pojawiały się nawet na poziomie klasy pierwszej szkoły podstawowej w przypadku uczniów o rozwiniętych umiejętnościach komunikacyjnych w języku polskim. „Jest jeszcze problem z rozumieniem poleceń, chłopiec często odmawia robienia jakiegoś zadania, mówi, że to jest głupie, nie będzie tego robił, ale mama tłumaczy, że to może wynikać z tego, że on czegoś nie wie, nie rozumie poleceń. Na pewno potrzeba trochę czasu jeszcze, żeby te polecenia do niego szybciej trafiały” [WN2].

W wypowiedziach dzieci reemigrantów, jak również ich rodziców i nauczycieli, pojawiają się również takie tematy, jak: narażenie na frustrację z powodu nieudanej 
adaptacji szkolnej, nieadekwatności osiągnięć szkolnych w stosunku do podejmowanych wysiłków, niebezpieczeństwo wykluczenia ze społeczności klasowej aż po ryzyko dyskryminacji ze względu na inność kulturową ucznia powracającego. Jak zauważył jeden z rodziców: „Uczniowie odnoszący sukcesy w zagranicznych szkołach po powrocie do kraju, zmianie języka, systemu, są narażeni na frustrację, bo nie tylko nie otrzymują wsparcia, ale odnoszą porażki” (Białek, 2015, s. 9)6.

Uczestnicząca w badaniu niezależna ekspertka, a jednocześnie psycholog zajmująca m.in. się problemami adaptacji dzieci z doświadczeniem migracyjnym, wskazuje na szereg potencjalnych problemów natury psychicznej, które mogą pojawić się u ucznia powracającego, funkcjonującego po pierwszym okresie powierzchownego zainteresowania ze strony na klasy na jej marginesie:

Uczeń powracający dla klasy często niestety na początku, tuż po dołączeniu do klasy, taki uczeń pełni rolę maskotki (»Mówisz po angielsku jak z Internetu«), ale po jakimś czasie się nudzi i trafia na margines klasy [...]. Zdarza się, że są to także uczniowie z różnymi ograniczeniami psychicznymi (np. uczniowie ze stanami depresyjnymi lub zachowaniami aspołecznymi, będącymi wynikiem np. drogi migracyjnej bądź wymuszonej migracji, bądź rozłąki rodzinnej) lub kulturowymi [...] (nie mają kompetencji kulturowej, która pozwoliłaby im być w pełni zaakceptowanym i zrozumianym w polskiej klasie), którzy wymagają wsparcia psychologicznego i kulturowego [WE1].

\section{MIĘDZYKULTUROWE OTWARCIE SZKOŁY JAKO BUDOWANIE ŚRODOWISKA WŁĄCZAJĄCEGO}

Międzykulturowe otwarcie szkoły wydaje się odpowiedzią na potrzeby ucznia z doświadczeniem migracyjnym, w tym ucznia powracającego. Jest szczególnie ważne w przypadku uczniów powracających, których historia migracyjna bywa niedoceniana przez nauczycieli, a różnice kulturowe - bagatelizowane. Umożliwia budowanie szkolnego środowiska włączającego, w którym mali remigranci odnajdują swoje miejsce, a nie są izolowani. Zgodnie z ideami pedagogiki międzykulturowej pozwala nie tyle koncentrować się na deficytach ucznia, ale rozwijać jego potencjał, chociażby językowy. W międzykulturowe otwarcie wpisane jest

${ }^{6}$ Por. wypowiedź ucznia o podobnym znaczeniu: „Denerwuję się, że tutaj ciągle jestem najsłabsza. W Niemczech byłam całkiem dobra [a tutaj nie] [...], a naprawdę dużo się uczę” (Białek, 2015, s. 24). 
pozytywne wartościowanie wielojęzyczności, traktowanej właśnie jako potencjał dziecka, nie zaś jako problem dla nauczyciela. Uczeń może być na lekcji wzorem językowym, przykładem dobrej wymowy itp., „native speakerem”, z którego pomocy klasa może skorzystać. Dziecku łatwiej odnaleźć się w zespole klasowym, kiedy dostrzegane są również jego mocne strony, jak chociażby znajomość innych języków niż polski. Uelastycznienie systemu edukacji pozwala na pełniejszą indywidualizację kształcenia, tak aby nie tylko służyło ono wyrównaniu braków ucznia powracającego, ale umożliwiało jego rozwój w obszarach, w których się wyróżnia. Poza językami takim obszarem, który pozwala uczniowi zdobyć uznanie w oczach klasy, jest na przykład sport.

W otwartej na międzykulturowość szkole nauczyciele, pedagog i psycholog pracują w zespole, aby dzielić się swoimi spostrzeżeniami, wiedzą i doświadczeniami. Do współpracy zaproszeni są też rodzice, którzy mogą z innej niż dziecko perspektywy przedstawić historię migracyjną rodziny, różnice w kulturze organizacyjnej szkoły czy standardy kulturowe kraju, z którego przyjechali. Personel szkoły dokształca się w zakresie kompetencji międzykulturowych oraz radzenia sobie z różnorodnością w szkole. Pożądane jest tutaj wsparcie eksperta od kwestii kulturowych i międzykulturowych. Zmiana dotyka całego środowiska szkolnego, które współtworzą uczniowie, nauczyciele i rodzice, współpracujący na zasadach partnerskich. Otwarta szkoła sprzyja udanej adaptacji szkolnej ucznia powracającego, jak również integracji jego oraz jego rodziny. Tym samym może stać się remedium na ryzyko pętli migracyjnej. Jednocześnie służy całej społeczności szkolnej i wszystkim uczniom, podkreślając indywidualność każdego z nich, w tym w tym ucznia z doświadczeniem migracyjnym, zgodnie ze słowami jednej z nauczycielek uczestniczącej w badaniach: „Uczniowie powracający są specyficzni, tak... I cóż z tego? Nie tylko oni...” [NW2].

Międzykulturowe otwarcie instytucji, w tym szkoły, jest ideą, która znajduje swoje przełożenie na praktykę społeczną i edukacyjną nie tylko w Niemczech, skąd się wywodzi. Warto przyjrzeć się gdańskiemu Modelowi Integracji Imigrantów (Fedas, Siciarek, Olech, 2015), który został przyjęty jako polityka miasta w tym obszarze ${ }^{7}$, powstał natomiast w odpowiedzi na potrzeby samych migrantów mieszkających w Gdańsku. Model został zainicjowany oddolnie, w ramach działań o charakterze partycypacyjnym wspieranych przez Urząd Miejski (Wydział Rozwoju Społecznego) oraz jedną z wiodących organizacji pozarządowych zajmujących się wsparciem imigrantów (Centrum Wsparcia Imigrantów i Imigrantek).

${ }^{7}$ Model jest obecnie podstawą do opracowywania polityk integracyjnych dla metropolii trójmiejskiej i województwa pomorskiego. 
Gdańsk od zawsze był miastem wielokulturowym, skupiającym przedstawicieli różnych nacji. Dziś przyciąga cudzoziemców, którzy przyjeżdżają, aby tam mieszkać, kształcić się, pracować czy też prowadzić interesy; przyjeżdżają też grupy szukające opieki i bezpieczeństwa, jak uchodźcy z Ukrainy czy Czeczeni. Imigranci funkcjonują w przestrzeni społecznej miasta, na co dzień kontaktują się z różnymi instytucjami, takimi jak urzędy pracy czy ośrodki zdrowia, ich dzieci uczęszczają do szkół i przedszkoli. Wszystkie te instytucje, odpowiadające za codzienne życie imigrantów, wymagają międzykulturowego otwarcia, które pozwoliłoby na traktowanie nowych mieszkańców jak pełnoprawnych obywateli miasta, którzy mogą przyczyniać się do jego rozwoju.

Gdański Model Integracji Imigrantów został wypracowany w 2015 roku przez międzysektorowy zespół, zrzeszający przedstawicieli ponad 70 instytucji publicznych oraz organizacji trzeciego sektora, z uwzględnieniem środowisk imigranckich. Prace polegały na comiesięcznych spotkaniach i pracach w tematycznych grupach roboczych, takich jak m.in.: edukacja, kultura, pomoc społeczna czy opieka zdrowotna. Spotkaniom towarzyszyły wsparcie ekspertów oraz szkolenia i seminaria, kierowane do całego zespołu oraz poszczególnych podzespołów, które umożliwiały dokształcenie się w temacie zaangażowanym w projekt osobom. Stworzone grupy miały objąć swoim zakresem funkcjonowanie imigrantów w różnych obszarach życia społecznego i zaprojektować działania włączające w tych obszarach. Praca w grupach roboczych umożliwiła spotkanie i wymianę informacji oraz doświadczeń między przedstawicielami różnych instytucji i organizacji, doprowadziły do powstania swego rodzaju sieci wsparcia działającej na rzecz integracji społecznej w ramach miasta i zapoczątkowały współpracę międzysektorową ${ }^{8}$ (por. Jaworska, Aleva, 2015).

Gdański Model pokazuje, jak międzykulturowe otwarcie może wyglądać w praktyce, w odniesieniu do szeregu miejskich instytucji, w tym placówek oświatowych. Kolejne szkoły, których przedstawiciele biorą udział w pracach nad Modelem, zmierzają w kierunku tworzenia środowiska otwartego międzykulturowo. Model pokazuje, że szkoła nie funkcjonuje w oderwaniu od swojego otoczenia społecznego. Pozwala również dostrzec jej znaczenie dla adaptacji społeczno-kulturowej dziecka i całej rodziny oraz integracji społecznej.

Uczeń powracający wraz ze swoimi rodzicami również podlega procesom adaptacji i integracji (Berry, 1997), które bywają nazywane „readaptacją” i „re-

8 W grupie „Edukacja” udało się skupić nauczycieli, pedagogów, dyrektorów, przedstawicieli kuratorium i poradni psychopedagogicznych oraz uczelni wyższych, co zapewnia ogląd sytuacji ucznia z doświadczeniem migracyjnym z różnych perspektyw oraz wymianę doświadczeń i informacji na temat dzieci i młodzieży ze środowiska imigranckiego między przedstawicielami różnych instytucji. 
integracją” (por. Grzymała-Kazłowska, 2008), choć nie zawsze jest to słuszne, gdyż powrót dla dziecka często wcale nie jest powrotem, a właśnie imigracją, wymuszającą odnalezienie się w całkiem nowych warunkach i odmiennej od tej znanej rzeczywistości. Istnieje też ryzyko wykluczenia społecznego w sytuacji nierówności edukacyjnych i znaczących różnic kulturowych, bagatelizowanych przez nauczycieli (por. Błeszyńska, 2011). Odniesienie idei otwarcia międzykulturowych do funkcjonowania uczniów z rodzin migrantów pokazuje, że nie tylko dzieci cudzoziemskie korzystają na otwartych na międzykulturowość zasadach funkcjonowania instytucji. Równie dobrze możemy wskazać inne grupy, które profitują na międzykulturowym otwarciu. Będą to uczniowie wykluczeni społecznie, niedostosowani, o specjalnych potrzebach. Okazuje się, że rację miała moja rozmówczyni, mówiąc, że „Uczniowie powracający są specyficzni [...] [ale »specyficzni są«] Nie tylko oni...” [NW2]. W końcu szkoła jest przestrzenią społecznej różnorodności, laboratorium funkcjonowania współczesnego społeczeństwa, tym samym idea (i praktyka!) międzykulturowego otwarcia, czy może lepiej „otwierania”, zyskuje na znaczeniu oraz na uniwersalności.

\section{Bibliografia}

Auernheimer, G. (2017). Wprowadzenie do pedagogiki międzykulturowej. Wprow. I tłum. K. Stankiewicz. Pruszków: Oficyna Wydawnicza LEKSEM.

Berry, J. (1997). Immigration, acculturation, adaptation. Applied Psychology, 46(1), s. 5-34. Białek, K. (red.). (2015). (Z)Powrotem w Polsce. Wyzwania i potencjał powracajacych do Polski. Pobrane z: http://www.msz.gov.pl/resource/c4666de6-dedf-43f5-8c71ff0653db9617:JCR.

Białek, K. (red.). (2016). (Z)Powrotem w Polsce. Poradnik dla osób powracajq̨cych do Polski. Pobrane z: https://www.stopociech.pl/s/images/stories/download/Senat_2016_ Publikacja_Z_Powrotem_w_Polsce.pdf.

Błeszyńska, K. (2010). Dzieci obcokrajowców w polskich placówkach oświatowych perspektywa szkoły. Raport z badań. Warszawa: Ośrodek Rozwoju Edukacji.

Błeszyńska, K. (2011). Dzieci imigrantów i uchodźców jako grupa zagrożona wykluczeniem społecznym. W: T. Lewowicki, A. Szczurek-Boruta, J. Suchodolska (red.), Pedagogika międzykulturowa wobec wykluczenia i edukacyjnego (s. 181-190). Cieszyn-Warszawa-Toruń: Wydawnictwo Adam Marszałek.

Fedas, A., Siciarek, M., Olech, P. (red.). (2016). Model integracji imigrantów. Gdańsk: Urząd Miejski w Gdańsku.

Fullan, M. (1995). The school as a learning organization: Distant dreams. Theory Into Practice, 34, s. 230-325.

Grzymała-Kazłowska, A. (2008). „Integracja” - próba rekonstrukcji pojęcia. W: A. Grzymała-Kazłowska, S. Łodziński (red.), Problemy integracji imigrantów. Koncepcje, badania, polityki (s. 29-50). Warszawa: Wydawnictwo Uniwersytetu Warszawskiego. 
Grzymała-Moszczyńska, H., Grzymała-Moszczyńska, J., Durlik, J., Szydłowska, P. (2015). (Nie)łatwe powroty do domu? Funkcjonowanie dzieci i młodzieży powracajacych z emigracji. Warszawa: Fundacja Centrum im. prof. Bronisława Geremka.

Handschuck, S., Schröer, H. (2012). Interkulturelle Orientierung und Öffnung - Theoretische Grundlagen und 50 Aktivitäten zur Umsetzung. Augsburg: Ziel Verlag.

Iglicka, K. (2010). Powroty Polaków po 2004 roku. W pętli pułapki migracji. Warszawa: SCHOLAR.

Januszewska, E. (2015). Uczeń cudzoziemski w polskiej szkole. Założenia teoretyczno-badawcze. Journal of Modern Science, 4(27), s. 11-32.

Jaworska, D., Aleva, K. (2015). W drodze. Gdańskie modele współżycia na styku z imigrantami. W: M. Mendel (red.), Miasto jak wspólny pokój: gdańskie modi co-vivendi (s. 147-169). Gdańsk: Gdańskie Towarzystwo Naukowe, Instytut Kultury Miejskiej.

Latek, M. (2017). Reintegration of returning migrants. European Parliamentary Research Service. Pobrane z: http://www.europarl.europa.eu/RegData/etudes/BRIE/2017/608779/ EPRS_BRI(2017)608779_EN.pdf.

Leiprecht, R. (2008). Von Gender Mainstreaming und Interkultureller Öffnung zu Managing Diversity - Auf dem Weg zu einem gerechten Umgang mit sozialer Heterogenität als Normalfall in der Schule. Lehrerfortbildung, 42, s. 8-14.

Schanz, C. (2006). Visionen brauchen Wege - Die interkulturelle Öffnung der Schule. W: R. Leiprecht, A. Kerber (red.), Schule in der Einwanderungsgesellschaft. Ein Handbuch (s. 110-125). Schwalbach i. T.: Wochenschau.

Schmitt, C. (2016). Inklusion, Interkulturelle Öffnung, Diversity - Professionstheoretische Überlegungen zu einem kritisch-reflexiven Inklusionsverständnis. Zeitschrift für Inklusion, 2. Pobrane z: http://www.inklusion-online.net/index.php/inklusion-online/ article/view/365/295.

Schröer. H., Szukitsch, Y. (2016). Interkulturelle Öffnung kommunal. Monachium: Netzwerk Interkulturelle Öffnung Kommunen Bayern.

Sosnowska, A., Ratajczak, J., Brzeziński, M., Korzeniewska, A. (2017). Raport: Jak i dokq̨d przeprowadzajq się Polacy? Pobrane z: https://clictrans.pl.

Vanderheiden, E., Mayer, C.-H. (2014). Einführung. Interkulturelle Öffnungsprozesse gestalten. W: E. Vanderheiden, C.-H. Mayer (red.), Handbuch Interkulturelle Öffnung: Grundlagen, Best Practice, Tools (s. 21-26). Goettingen: Vandenhoeck \& Ruprecht. 